\title{
ROLE OF WAGES, INDUSTRIAL SECTOR AND THE GDP AGAINST JOB OPPORTUNITIES IN NGAWI REGENCY PERIOD 1987 - 2015
}

\author{
Diyan Roffiani Puspitasari ${ }^{1}$ \\ Akhmad Daerobi \\ Siti Aisyah
}

Universitas Sebelas Maret

roffianidian@gmail.com ${ }^{1}$

\begin{abstract}
This study aimed to analyze the influence of the regional minimum wage, the number of industrial and Gross Domestic Product (GDP) on employment in Ngawi year period 1987-2015. This research is explanatory because it is used in testing hypotheses. The unit of analysis in this study is data on the regional minimum wage, the number of industrial and Gross Domestic Product (GDP) and employment opportunities in Ngawi-year period from 1987 to 2015 were obtained from the Central Statistics Agency of East Java Province. Data were analyzed using Error Correction Model (ECM). The study found that: regional minimum wage, the number of industrial and Gross Regional Domestic Product (GRDP) a positive role in promoting employment in Ngawi-year period 1987-2015.
\end{abstract}

Keywords: employment, regional minimum wage, the number of industrial, Gross Domestic Product (GDP), Error Correction Model (ECM)

\section{INTRODUCE}

Economic development is expected to be a solution to the problem of poverty by providing employment opportunities to the widest public. Vision Mission President Joko Widodo as stipulated in RPJMN, national development vision for the years 2015-2019 is: "Realization of Indonesia Sovereign, Independent, and personality of Mutual-Based Mutual". Independent society would be realized if the poverty rate could be reduced and public welfare can be improved. For that efforts to reduce poverty should always be done for the creation of the national development vision. All walks of life can enjoy the fruits of development, especially the people who are still in the category of underprivileged need attention in the preparation of pro-poor policies.

Economic activity covers all human needs and its resources are not unlimited, and how people can meet their needs (how) with the resources that are scarce. To meet the needs, human economic activity which includes production in which the human resources or human resources implies that humans are able to work to contribute to the services or activities that have economic value. Simply put labor is defined as the population of working age (Simanjuntak, 2001: 4).

Labor certainly need a job in order to be accommodated in a particular job. But the reality is not all work tenanga have a chance to get a job. This will certainly lead to the rise 
of unemployment. Unemployment is a very complex issue, it means tackling unemployment also needs proper analysis, involving all the components of the problems, sustainable and not temporary. Unemployment or out-of-work is a term for people who do not work at all, are looking for work, working less than two days during the week, or someone trying to get a decent job. Unemployment is generally caused because the workforce or job seekers are not proportional to the number of jobs that exist are able to absorb it. Unemployment is often a problem in the economy due to unemployment, productivity and incomes will be reduced so that it can cause poverty and other social problems.

Employment opportunities need to be created so that the problem of unemployment can be resolved. Job opportunities are not only about the problems in the economy, but also in the social sector, especially in times of economic crisis some time ago. Employment issues are almost in all countries today in both the developed and developing countries. It was seen from always the departments in charge of labor on each cabinet is formed.

The problem of employment is not just about the availability of jobs for the labor force, but also whether the existing employment can reasonably able to provide sufficient returns for the workers. Availability of jobs can not be separated from the development that can be seen from both the investment activities of domestic and foreign investment to the year there was an increase. Job opportunities illustrate the magnitude of the demand for labor in an economy. Investment factor can directly increase the production capacity (such as capital equipment) which will increase the demand for labor factors of production. With the increase of capital goods as a result of investment activities it will encourage the expansion of employment opportunities. Factors can affect the wage rate of labor demand. Improvement of wages is essential to support the development. With the improvement of wages will be an increase workers' income and purchasing power. With the improvement of people's income will increase the demand for goods and services that will make the development of the companies that were there. Repair wages may encourage the creation of new jobs and increase productivity (Rahmawati, 2013).

Rahmawati above findings show there is a relationship between the level of wages with the development of the industry in order to increase employment opportunities. MSE (Minimum Wages District / City) Ngawi in 2016 amounted to Rp. 1,334,000.00 occupies the lowest position compared to the five District/ Other cities in East Java province. This condition when compared with the above research findings will make people's purchasing power in Ngawi becomes low. Low buying power is thought to inhibit the development of the industrial sector as demand for industrial products produced too low. When the development of the industrial sector is low, employment opportunities in the district of Ngawi too low. The labor force is generated from both formal and informal sector can not be accommodated because of the lack of job opportunities. This will potentially lead to high levels of unemployment.

The industrial sector is believed to bring about change in a country's economy towards progress. The industrial sector has an important role to support economic growth sustainable high and increasing physical production community through the expansion of the business field and expanding employment opportunities, enhance and conserve foreign exchange, encourage regional development, to improve and smooth the revenue of society as well as poverty alleviation. (Mahendra, 2013).

The above explanation shows the importance of careful planning in public policies governing labor. Planning long-term policy would do better to support existing data 
current and previous years, so they will know how much impact the establishment of regional minimum wage, the number of industrial and Gross Domestic Product (GDP) on employment for people in the District Ngawi. Through analysis of the various factors that were related to employment opportunities, will be known picture of the condition in the future as the basis for the policy makers.

\section{LITERATURE REVIEW}

\section{Employment Opportunity}

According to Sagir(2000: 17) employment is: The opportunity to try and participate in development, will clearly provide for the human right to enjoy the fruits of development. According Tjiptoherijanto (2001: 36) states: The economic approach that heeds only the increase in GDP will not succeed in improving the quality of Human Resources. While the human resource approach promises economic growth that is balanced with equity, both employment and income.

\section{Wage}

According Hasibuan (2007: 92), wages are the remuneration paid to daily workers by referring to the agreement agreed to pay. While Simanjuntak (2001: 104), states that wages reward one receives for services rendered to others, given entirely in cash or partly in cash and partly in the form of natural.

\section{Industry}

Industry Definition according Sukirno (2000: 54 ) is the company that runs the economic activity belonging to the secondary sector. The activities include textile factories, assembly plants and cigarette manufacturing plant. Industry is an economic activity that processes raw materials, raw materials, semi-finished goods or finished goods for goods made in the higher usefulness.
Law No. 5 of 1984 regarding Industry cited Wignjosoebroto (2003: 19) industry is an economic activity which manages raw materials, raw materials, semi-finished goods, and or finished goods into goods with a higher value for their use, including design activities wake and industrial engineering.

\section{Gross Regional Domestic Product (GRDP)}

In general, economic growth was defined as an increase of an economy producing goods and services. In other words the direction of economic growth over the changes which are quantitative (quantitative change) and usually is calculated using data of Gross Domestic Product (GDP) or income or the value end of the market (total market value) of final goods and services (final goods and service) resulting from an economy over a certain period of time and is usually one year.

To calculate the nominal economic growth can be used the GDP (Gross Domestic Product). GRDP used for many purposes but the most important is to measure the performance of the overall economy. This amount will be equal to the total nominal value of consumption, investment, government spending on goods and services, and net exports.

\section{Research Accomplished}

The study discusses about the effect of wages on employment is as follows: Rahmawati study (2013) found the test results simultaneously $0.001538<\alpha(0.05)$ which can be concluded that there are significant efect between investment and the level of wages on employment in East Java. For the results of research partially for investment $0.8725>0.05$ it can be concluded that the investment variable has no significant effect on employment in East Java. While the results of partial testing for the level of wages $0.0088>0.05$, it can be concluded that the wage level variables 
affect significantly the variable employment. The coefficient of determination (R2) of 0.842863 showing that 84.2 percent of the rise and fall of employment in variables affect investment and the level of wages while the remaining 15.8 percent is influenced by other factors.

Research Neumark (2015) found that the current minimum wage has been directly reduces the amount of work nationwide about 100,000 to 200,000 , compared with the period before the Great Recession. It was a small decline in aggregate job that must be weighed against the increase in income for workers who are still working for a higher minimum wage. Sulistiawati study (2012) found that (1) Wages significant influence and has a negative correlation to employment; (2) Labor absorption effect is not significant and have a positive relationship to the welfare of society; (3) The minimum wage received by workers under the limit Not Taxable Income or taxable income.

Research Budisusilo, Viphindrartin and Wibisono (2015) indicates that the variable Minimum Wages District (UMK) negative and not significant with a probability value $\mathrm{t}_{\text {count }} 0.179 \%$, Gross Domestic Product (GDP) has positive and significant with a probability value $t_{\text {count }}$ of $0.014 \%$, Foreign Direct investment (FDI) negative and not significant with a probability value $\mathrm{t}_{\text {count }}$ of $0.066 \%$ and domestic investment (DCI) has positive and significant with a probability value $t_{\text {count }}$ of $0.021 \%$ on employment in trade, hotels and restaurants in Banyuwangi. Kalenkoski Research (2016), found that the minimum wage negatively affect youth employment opportunities. The minimum wage is not the best way to improve labor market of young skilled people. The lack of experience of young workers create opportunities to get a job at minimum wage to be low.

The study discusses the variable number of industries are as follows: Mahendra study (2013) found that the number of variables cient koefi -3757 industry, the production capacity of 10708 variable coefficients are statistically significant at $\alpha=5 \%$. Variable number of industries negatively affect production capacity while variable positive effect on employment in the timber industry lathe in Sub responsibility of Blitar. Research Morozova, et.al. (2015), found that the development of the tourism industry made a positive impact on employment in the Yaroslavl region. This is in line with the results of research Gaudel (2016) who found that the positive effect of industrial development on employment in Nepal.

The study discusses the influence of the GDP on employment is as follows: Research Sobita and Suparta (2014) in Lampung Province found that the independent variable real GRDP prices and capital in agriculture significantly positive effect on employment. The increase in real GRDP and capital in agriculture will increase employment. Meanwhile Variable Real wages significantly negative effect on employment. The increase in real wages will decrease the absorption of Labor. Umair research and Ullah (2013), found that (1) inflation has no significant effect on employment in Pakistan in 2000-2010, (2) PDRB significant effect on employment opportunities in Pakistan in 2000-2010.

\section{Conceptual Framework}

Conceptual framework in this study can be described as follows:

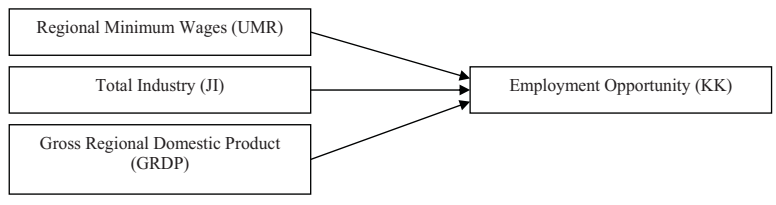

Figure 1. Conceptual Framework

\section{HYPOTHESIS}

a. Regional Minimum Wages positive effect on Employment Opportunity in Ngawi-year period 1987-2015. 
b. Total industry positive effect on Employment Opportunity in Ngawi-year period 19872015.

c. Gross Regional Domestic Product (GDP) has positive effect on Employment Opportunity in Ngawi-year period 1987-2015.

\section{RESEARCH METHOD}

This research is a quantitative research. This is because in the activities of this study researchers used figures in collecting data and in providing interpretation of the results and analyzed by statistical analysis form. In this study, the unit of analysis is the data about the regional minimum wage, the number of industrial and Gross Domestic Product (GDP) and employment opportunities in Ngawi-year period from 1987 to 2015 were obtained from the Central Statistics Agency of East Java Province.

Data analysis techniques in this study using a Model Error Correction or Error Correction Model (ECM). The processing of data with ECM approach, there are several stages to go through. Stages, among others; stationarity test, cointegration test and test ECM. ECM equation model on elitian pen is as follows:

$\mathrm{KKt}=\beta 0+\beta 1 \Delta \operatorname{LogUMRt}+\beta 2 \Delta \mathrm{JIt}+$ $\beta 3 \Delta \operatorname{LogPDRBt}+\mathrm{ECTt}-1$

Which one:

KK $=$ Employment Opportunity

$\operatorname{LogUMR}=$ Regional minimum wage

$\mathrm{JI}=$ Total Industry

$\operatorname{LogPDRB}=$ Gross Regional Domestic

Product

$\beta 0=$ number constants

$\beta 1, \beta 2, \beta 3=$ regression coefficients

ECTt-1 = Error Correction Term

\section{RESULTS AND DISCUSSION Stationary Test Data}

Table 1

Results of Stationary Test Data

\begin{tabular}{|l|c|c|c|c|c|c|}
\hline \multirow{3}{*}{ Variable } & \multicolumn{6}{|c|}{ Unit Root Test } \\
\cline { 2 - 7 } & \multicolumn{2}{|c|}{ Level } & \multicolumn{2}{|c|}{$1^{\text {st }}$ Difference } & \multicolumn{2}{|c|}{$2^{\text {nd }}$ Difference } \\
\cline { 2 - 7 } & ADF & prob & ADF & prob & ADF & prob \\
\hline UMR & 4.255440 & 1.0000 & 2.675324 & 1.0000 & -7.0672 & 0.0000 \\
\hline JI & -0.1139 & 0.9367 & -4.028916 & 0.0054 & -3.6272 & 0.0132 \\
\hline PDRB & 0.870696 & 0.9935 & -4.01216 & 0.0048 & -3.5141 & 0.0179 \\
\hline KK & -3.45256 & 0.0185 & -3.751071 & 0.0104 & -4.1999 & 0.0043 \\
\hline
\end{tabular}

Source: Data Eviews6 2016

Based on the data in Table 1 it can be seen that all variables are not stationary at the level of data that needs to be repeated on a stationary test data is 1 st difference. Data on the 1st difference is known not all variables are stationary because of variable data Minimum Wage (UMR), Total Industry (JI) and the Gross Regional Domestic Product (GRDP) has a probability of $>0.05$, only variable Employment Opportunities (KK) are already stationary, Stationary test was repeated on the 2nd of data difference, the result has been stationary for all variables probability value of less than 0.05 .

\section{Cointegration Test}

Table 2

Cointegration Test Results

\begin{tabular}{|l|c|c|}
\hline $\begin{array}{l}\text { Variable Cointegration } \\
\text { test results }\end{array}$ & T statistic & prob \\
\hline ect & -4.490614 & 0.0014 \\
\hline
\end{tabular}

Source: Data Eviews6 2016

Based on the data in Table 2 above it can be seen that the residual value stationary. It can be seen from the value of the $t$-statistic is significant at the $5 \%$ critical value is the probability of 0.0014 . Thus we can say that the data are cointegrated.

The next step is to test the long-term cointegration then double-log model is created, the data in the $\log$ is the minimum wage and the GDP. Based on calculations using the 
assistance program Eviews6 obtained long-term cointegration test results as shown in Table 3.

\section{Table 3}

\section{Cointegration Test Results after Doubel Log}

\begin{tabular}{|l|c|c|}
\hline $\begin{array}{l}\text { Variable Cointegration } \\
\text { test results }\end{array}$ & T statistic & prob \\
\hline ect & -3.850641 & 0.0075 \\
\hline
\end{tabular}

Source: Data Olah Eviews6 2016

Based on the data in Table 3 above it can be seen that the residual value stationary. Residual must be stationary at the current level to be said to have cointegration. Variable cointegration test results found that the value of t-statistic dignifikan the critical value of $5 \%$ ie with probability 0.0075 , thus it can be said that the data are cointegrated.

\section{Model ECM}

Table 4

Test Error Correction Model (ECM)

\begin{tabular}{|c|r|r|r|r|}
\hline variable & coefficient & Std. Error & t-Statistic & Prob. \\
\hline C & -88.30916 & 221.1795 & -0.399265 & 0.6934 \\
\hline D (LOGUMR) & 285.9747 & 1257.944 & 0.227335 & 0.8222 \\
\hline D (JI) & 0.368094 & 0.217526 & 1.692185 & 0.1041 \\
\hline D (LOGPDRB) & 190.7028 & 412.3600 & 0.462467 & 0.6481 \\
\hline ECT (-1) & -0.761067 & 0.189228 & -4.021964 & 0.0005 \\
\hline R-squared & 0.448859 & Mean dependent var & 28.10714 \\
\hline Adjusted R-squared & 0.353008 & SD dependent var & 596.1069 \\
\hline SE of regression & 479.4834 & Akaike information criterion & 15.34373 \\
\hline Sum squared resid & 5287799 & Schwarz criterion & 15.58162 \\
\hline Log likelihood & -209.8122 & Hannan-Quinn criter. & 15.41645 \\
\hline F-statistic & 4.682898 & Durbin-Watson stat & 1.429159 \\
\hline Prob (F-statistic) & 0.006520 & & & \\
\hline
\end{tabular}

Source: Data Eviews6 2016

Based on the data in Table 4.6, the ECM equation model in this study are as follows:

$\mathrm{D}(\mathrm{KK})=-88.30916+285.9747 \mathrm{D}($ LOGUMR $)+$ $0.368094 \mathrm{D}(\mathrm{JI})+190.7028 \mathrm{D}(\mathrm{LOGPDRB})$ -0.761067 ECT(-1)

Error equation model Correc tion Model (ECM) above can be explained as follows:

a. $\quad \beta 0=-88.30916$, meaning without the variable regional minimum wage (UMR), the number of industries (JI) and the regional gross domestic product (GDP), the contribution of variable employment (KK) is equal -88.30916 .

b. $\beta 1=285.9747$, meaning if the variable regional minimum wage (UMR) is increased by 1 unit, there will be an increase in employment (KK) of 285.9747 and consider other variables, namely the number of industries (JI) and $\mathrm{d}$ omestik gross regional product ( GRDP) is constant.

c. $\beta 2=0.368094$, meaning if a variable number of industries (JI) is increased by 1 unit, there will be an increase in employment (KK) of 0.368094 and consider other variables, namely the regional minimum wage (UMR) and gross regional domestic product (GRDP) is constant.

d. $\beta 3=190.7028$, meaning if the variable gross regional domestic product (GDP) increased by 1 unit, there will be a decrease in employment (KK) of 190.7028 and men ganggap other variables that the regional minimum wage (UMR) and a number of industries ( JI) is constant.

\section{Discussion}

The results of the data analysis above it can be seen the value of Adjusted $\mathrm{R}^{2}$ is 0.353 . This means that independent variable that consists of the regional minimum wage (UMR), the number of industries (JI) and the gross regional domestic product (GRDP) is able to explain the variable employment (KK) of $35.3 \%$, while the remaining $64.7 \%$ influenced other factors not discussed in this study. Data in Table 4.6 also discovered the value of F-statistic with a value of 4.682898 Prob (F-statistic) of $0.006520<0.05$. This means that the regional minimum wage (UMR), the number of industries (JI) and the gross regional domestic product (GRDP) jointly have a significant effect on the variable employment (KK)

Based on equation model Error Correction Model (ECM), can discuss the relationship between variables in this study as follows: 


\section{Wage Effect of Regional Drinking against Job Opportunities}

The regression coefficient variable regional minimum wage (UMR) is equal to 285.9747. This means that the regional minimum wage a positive effect on employment. Thus the hypothesis $U$ pah regional minimum positive effect on employment in Ngawi-year period 1987 - 2015 proven and accepted as true. Increasing the minimum wage will increase employment opportunities in Ngawi.

The results of this study do not support the findings of previous studies conducted by Sobita and Suparta (2014) that real wages significantly negative effect on employment. The results of this study do not support the research findings Sulistiawati (2012) that (1) Wages significant influence and has a negative correlation to employment. Research Budisusilo, Viphindrartin and Wibisono (2015) indicates that the variable Minimum Wages District (UMK) and no significant negative effect on employment in the trade, hotel and restaurant in Banyuwangi, so these findings are not the same as the results of this study.

The results support the findings of the study Rahmawati (2013) because both found the regional minimum wage a positive effect on employment. With the improvement of wages will be an increase workers' income and purchasing power. With the improvement of people's income will increase the demand for goods and services that will make the development of the companies that were there. Repair wages may encourage the creation of new jobs and increase productivity.

Ngawi regency government needs to be more careful in determining the Regional Minimum Wage (UMR) or the Minimum Wages District (UMK). UMR conditions Ngawi district that currently occupies the lowest position in East Java to five need attention in order to establish the exact UMR in order to encourage economic conditions but is still attracting investment from the private sector. It is expected the job opportunities can be improved.

\section{Effect of Total Industry to Employment}

The regression coefficient variable number of industries (JI) is equal to 0.368094 . This means the number of industries has positive effect on employment. Thus the hypothesis which says the number of industries has positive effect on employment in Ngawi-year period 1987 2015 proven and accepted as true. Total industry growing communities will increase employment opportunities in Ngawi.

The results support the findings of the study Morozova, et.al. (2015) that the development of the tourism industry made a positive impact on employment in the Yaroslavl region. The study also supports research Gaudel (2016) that the industrial development has positive effect on employment in Nepal. This study does not support the research findings Mahendra (2013) that the number of industries negatively affect employment in the timber industry lathe.

Ngawi regency government needs to make efforts so that an increasing number of industries. Step-by-step policy-making in the Medium Term Development Plan (Plan) need to be conditioned in order to attract investment. This can be done by creating a licensing system that is easy and fast as it has been proclaimed by the central government, includes exhibition of industrial products, as well as promoting the potential that exists in Ngawi widely.

\section{Effect of Gross Regional Domestic Product of the Employment Opportunities}

The regression coefficient variable gross regional domestic product (GDP) amounted to 190.7028 . This means that regional gross domestic product positive effect on employment. Thus the hypothesis Gross Regional Domestic Product (GDP) has positive effect on employment in Ngawi-year period 1987-2015 proven and 
accepted as true. The development of regional gross domestic product gives positive impact on employment in Ngawi.

The results support the findings of the study Sobita and Suparta (2014) that the independent variable real GRDP significantly positive effect on employment. The study also supports the research findings Umair and Ullah (2013) that the GDP have a significant effect on employment in Pakistan in 2000-2010.

Increased Gross Regional Domestic Product (GDP) would be accompanied by better economic growth. Improved economic growth are expected to provide greater employment opportunities to the community Ngawi. Ngawi regency government needs to increase investment to increase productivity so that a wide range of local commodities higher economic growth remains balanced with wider employment opportunities. The right investment with intensive policy is expected to be a solution for development that do can be sensed result by the wider society. Communities can obtain employment opportunities in the district of Ngawi.

\section{CONCLUSION}

\section{Conclusion}

Based on the analysis of data and discussion can take several conclusions as follows:

a. Regional minimum wages has positive role in improving employment opportunity at Ngawi Regency year period 1987-2015.

b. Total industry has positive role in improving employment opportunity at Ngawi Regency year period 1987-2015.

c. Gross Regional Domestic Product (GDP) has positive role in improving employment opportunity at Ngawi Regency year period 1987-2015.

\section{Suggestion}

Based on the conclusion, it can be put forward some suggestions as follows:

a. For the Government of Ngawi, need to consider the policy of regional minimum wages better the investment climate is getting better. Determination of high UMR will make the investment and reduced employment opportunities Ngawi Regency society.

b. Permerintah Ngawi need to increase efforts in order to attract investment in the industrial sector. An increasing number of industries will be able to provide job opportunities for the wider community in Ngawi.

c. Ngawi regency government needs to pursue policies that can enhance employment opportunities. Improved economic conditions were reflected in the Gross Regional Domestic Product (GRDP) need to be harmonized with the opportunity to earn a decent job in Ngawi.

d. For further research can be expanded by adding more variables so it can produce more complex research.

\section{REFERENCES}

Budisusilo, T., Viphindrartin, S., dan Wibisono, S., 2015, "Faktor-Faktor Yang Berpengaruh Terhadap Kesempatan Kerja Pada Sektor Perdagangan, Hotel Dan Restoran Di Kabupaten Banyuwangi”, Artikel Ilmiah Mahasiswa 2015.

Gaudel, S., 2016, "Entrepreneurs, Industries And Employment Opportunities In Nepal", International Journal of Research in Business Management (IMPACT: IJRBM), ISSN (E): 2321-886X; ISSN(P): 2347-4572 Vol. 4, Issue 5, May 2016, 85-98.

Hasibuan, M.S.P., 2007, Manajemen Sumber Daya Manusia, Jakarta: PT. Toko Gunung Agung. 
Kalenkoski, C.M., 2016, “The effects of minimum wages on youth employment and income", IZA World of Labor, March 2016, wol.iza.org, pp. 1-10.

Mahendra, R., 2013, "Pengaruh Jumlah Industri Dan Kapasitas Produksi Terhadap Penyerapan Tenaga Kerja Di Kota Blitar (Studi Pada Industri Kayu Bubut Di Kelurahan Tanggung Kota Blitar)", Jurnal Ilmiah Mahasiswa FEB, Vol. 1 No. 2 (2013).

Morozova, L.S., Ananjev, A.N., Morozov, V.Y., Havanova, N.V., \& Litvinova, E.V., 2015, "Influence of Tourism Industry Development on the Regional Labour Market (on the Example of the Yaroslavl Region)", Review of European Studies; Vol. 7, No. 3; 2015 ISSN 19187173 E-ISSN 1918-7181 Published by Canadian Center of Science and Education, pp 51-65.

Neumark, D., 2015, “The Effects of Minimum Wages on Employment", FRBSF Economic Letter, 2015-37, December 21, 2015.

Rahmawati, I.D., 2013, Pengaruh Investasi Dan Tingkat Upah Terhadap Kesempatan Kerja Di Jawa Timur, Jurnal Pendidikan Ekonomi (JUPE), Vol 1, No 3, (2013).

Sagir, Suharsono. 2000. Membangun Manusia Karya, Jakarta: Pustaka Sinar Harapan.

Simanjuntak, Payaman. 2001. Pengantar Ekonomi Sumber Daya Manusia. Jakarta: Universitas Indonesia Press.
Sobita, N. E., dan Suparta, I. W., 2014, "Pertumbuhan Ekonomi Dan Penyerapan Tenaga Kerja Di Provinsi Lampung", JEP, Vol. 3, N0 2, Juli 2014, hal. $141-166$.

Sukirno, Sadono. 2000. Ekonomi Pembangunan Proses, Masalah dan Dasar Kebijakan Pembangunan. Jakarta: Erlangga.

Sulistiawati, R., 2012, "Pengaruh Upah Minimum terhadap Penyerapan Tenaga Kerja dan Kesejahteraan Masyarakat di Provinsi di Indonesia”, Jurnal EKSOS, ISSN 1693 - 9093, Volume 8, Nomor 3, Oktober 2012, hal $195-211$.

Tjiptoherijanto, Prijono, 2001, “Proyeksi Penduduk, Angkatan Kerja, Tenaga Kerja, dan Peran Serikat Pekerja dalam Peningkatan Kesejahteraan", Majalah Perencanaan Pembangunan, Edisi 23.

Umair, M., and Ullah, R., 2013, "Impact of GDP and Inflation on Unemployment Rate: A Study of Pakistan Economy in 2000-2010", International Review of Management and Business Research, Vol. 2 Issue.2, June 2013, ISSN: 23069007, pp. 388-400.

Wignjosoebroto, S., 2003, Pengantar Teknik \&Manajemen Industri, Jakarta: Guna Widya.

Yasin, Makmun dan Akhmad, 2003, "Pengaruh Investasi dan Tenaga Kerja terhadap PDB Sektor Pertanian", Kajian Ekonomi dan Keuangan, Vol. 7, No. 3 Sept. 2003. 